\title{
CONSTRUCTION OF THE SUCCESS FACTORS OF IKAT WEAVINGS (A CASE STUDY OF AN IKAT WEAVING CRAFTSMAN UNDER THE BIA BEREK IKAT WEAVING GROUP - BELU REGENCY)
}

\author{
Ignatia Thomasita Bau Mau' ${ }^{{ }^{*}}$, Atim Djazuli ${ }^{1}$, Helmy Djawahir ${ }^{1}$ \\ ${ }^{1}$ Universitas Brawijaya, Indonesia \\ *e-mail: alfinaaisa19@gmail.com
}

\begin{abstract}
This study discusses the success factors in running a woven handicraft business experienced and immediately felt by several ikat craftsmen in one group of Bia Berek weaving in the city of Atambua, Belu Regency, East Nusa Tenggara. This is to direct the informant to answer all the success factors that have occurred and let the qualitative research model be used as a method in this research. The research used semi-structured interviews, and the informant reveals as widely as possible the informant regarding other factors that are also the key to success in running a business. These success factors include the proper management of current assets (supplies of woven fabrics) and fixed assets (weaving equipment and equipment and business premises), the ability to manage business turnover, cash flow management, the ability to process all business costs in the cost structure, management of revenue on weaving business, having personal savings and investing in non-bank financial services, increasing the marketing of woven fabrics, using technology for business innovation in the digital world, prioritizing the quality of woven fabrics produced, utilizing culture and tradition as business opportunities and potential, building profitable cooperation with local government of Belu Regency. The twelve factors that have been classified into financial and non-financial factors are constructed in a new model design that can be used as learning materials for micro, small and medium enterprises in improving their business by taking into account all the success factors that occur in their business.
\end{abstract}

Keywords: Success Factors; Ikat Weaving Craft Business; Craftsman

This is an open access article under the CC BY-SA license.

Copyright ( 2021 by Author. Published by Universitas Pendidikan Ganesha.

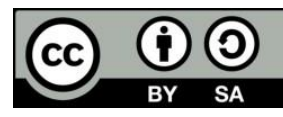

\section{INTRODUCTION}

The weaving group "Bia Berek" is really diligent in every process that it goes through to develop this business, therefore its success is not in doubt. The success of the production of beautiful woven fabrics, the benefits, the trust and satisfaction of consumers shown by always coming back to the Bia Berek weaving gallery has made this group already have a well-known name in Atambua, Belu Regency, East Nusa Tenggara. The success shown in the development of this woven handicraft business, especially the success of every craftsman who has tried to develop a woven handicraft business over the years until his group can be known by the wider community, makes researchers incri singly interested in knowing, studying and understanding what success factors are experienced and felt directly by the craftsmen in the Bia Berek Weaving group. The success factors that are felt and experienced by business actors in their various businesses can also be seen from several previous studies in this study, which review the dimensions of success that occur in small and medium enterprises from several countries.

Maher (2014), in his research on the success factors of small and medium enterprises (SMEs) based on a case study of SMEs in Jordan. The success factors revealed in this research are technical and technological procedures, company structure, financial structure, marketing 
and productivity and human resource structure. (Lauersen et al., 2011) in their research related two dimensions of success that affect small business actors in Western Australia, namely the financial dimension and the nonfinancial dimension. Dimensions nonfinancial included in this research that lifestyle (life style) which is a feeling of affective personally expressed by small business owners that are related to aspects of making money from a business carried and social responsibility (social responsibility) relating to responsibility a small business actor towards people in his business group, in other words, is responsible for members of the business group rather than for the individual. Meanwhile, the financial dimension in this study, namely financial strength (strong financial) is a traditional financial measure of business success, meaning that business actors end to run their business with the motivation to make as much money as possible and earn profits according to financial measures and two other reasons that are also related to financial strength. seen from the ambition of business actors in running a business, so that they are able to run and produce a successful business (Rafiki \& Nasution, 2019). It is more related to the personal ego, but has financial implications and diminished financial indicates that the financial aspect of business ownership diminishes over time.

Research conducted by (Chowdhury et al., 2013), related to assessing the factors that influence the success of small and medium entrepreneurs in Bangladesh, survey data were collected from eighty entrepreneurs from the southern region of Bangladesh through a random sampling technique. The success factors in this study refer to demographic characteristics and environmental factors (Lo et al., 2016); (Chowdhury et al., 2013). Demographic characteristics include age, education and experience while environmental factors include Marketing, Technology, Access to Capital, Infrastructure, Government, Politics and Access to Information. Research conducted by (Radzi et al., 2017) related to success factors that actually occur in small business actors in Malaysia using research subjects on small business actors who are incorporated or run their businesses, funded by an organization in Malaysia, namely FELDA. The Federal Land Development Authority (abbreviated as FELDA) is the Association for the Advancement of Land Partnership, a Malaysian government agency that handles the arrangement to funder developed rural areas in to new development areas.

This study reveals the success factors which include entrepreneurial competence, marketing ability, financial resources, use of technology, knowledge sharing and the success of the business itself. Based on the results of previous research which revealed the success factors that occurred in several different countries with the different business fields that business actors were engaged in, revealed various factors that differed according to the type of business, as well as the motivation (vision, mission and objectives) of the business being carried out. The success factor that occurs in one business is not necessarily the same success factor as other businesses in different countries or in other areas. This means that every business actor who develops his business feels his own success factor in accordance with what that business actor has actually experienced.

\section{METHODS}

In connection with the objectives of this research, to reveal the success factors of the ikat craftsmen in Belu Regency, constructivist approach is used to construct the meaning of the situation directly experienced by the craftsmen when running the weaving handicraft business that has been 
involved and to reveal clearly the success factors weaving handicraft business (Sale \& Thielke, 2018). The design in this study used a multiple case study (Hardjono \& van Kemenade, 2021), where the subjects in the study were five ikat craftsmen who take shelter in the "Bia Berek" weaving group. This research uses a methodological level, where the researcher constructs the success factors of the ikat business involved in the hermeneutical aspect (using interview guides, writing or pictures) and using the dialectic aspect (building direct dialogue with the subjects in the study who are active players in the ikat business. which takes shelter in the Bia Berek Weaving Group). From the data obtained in building thoughts between researchers and subjects in the study related to the success factors of the ikat craft business both hermeneutically and dialectically, the researcher constructs the success factors that are clearly expressed and realistically into interpretations of understanding in accordance with management science. And make it easier for readers to find out what success factors are going into the success factors chart.

This research was conducted to determine the success factor for the weaving craftsmen who are members of the "Bia Berek" Ikat Weaving group, which is addressed in Koneru, Manumutin sub-district, Atambua City district, Belu-NTT regency. The craftsmen who took shelter in the "Bia Berek" weaving group were chosen, because they were able to maintain the tie weaving business that has been in the business for years and the weaving business benefits the economy of the household foreach craftsman, so that it can be used as a subject. research to explore information about the success factors of these craftsmen. This study uses two types of data sources, namely primary (direct) data through observation and interviews, as well as secondary (library) data through documentation and visual materials to record or record information. First, primary (direct) data uses interviews. The interview was conducted with a weaving craftsman under the weaving group "Bia Berek", who runs a weaving business to support the household economy of the respective craftsmen. Second, secondary data (library) obtained from documents, archives, order records for woven fabrics (orderbooks)owned by each craftsman. This data is used to assist researchers in revealing the success factors of the weaving handicraft business experienced and felt by each craftsman.

\section{RESULT AND DISCUSSION Financial Factors}

\section{Current assets}

Craftsmen always meet the availability of woven fabrics that consumers demand, seek, or even demand. Every day the craftsmen always weave, the soda production process runs every day and the products produced, namely woven fabrics, are always in stock. When consumers come to look for woven fabrics, craftsmen always provide various choices of woven fabrics with various types of woven fabrics so that consumers can determine their choice of buying what kind of woven fabric product. When consumers visit Bia Berek's Mini gallery, the supply of woven fabrics is also sufficient for what consumers need so that there is selfsatisfaction that arises from consumers because they are always provided with the availability of woven fabrics that are always available both for the craftsmen themselves and in groups. The Aim of the craftsmen is to always fulfill the availability of woven fabrics both for the Bia Berek gallery and for supplies personally with the intention that when consumers visit the craftsmen individually or in groups, the craftsmen have a supply of woven fabrics that can be shown, marketed or sold to consumers in addition to the craftsmen completing orders from other 
consumers. This means that it is a must and commitment from the craftsmen to always provide woven fabric products at the production site of each craftsman (at home) and provide woven fabric products in the mini-Bia Berek Gallery. This commitment has been carried out over the years since this group was formed, and has been carried out individually when the craftsmen started running the weaving handicraft business. With the commitment made, it has a positive impact and is felt as a success factor in running a woven handicraft business, because with the availability of woven fabric products that are always there, consumers are always satisfied to buy woven fabrics from individual craftsmen or buy woven fabrics in galleries. Bia Berek, so that consumers come back (loyal) with the craftsmen as well as the weavings woven by the craftsmen supplies in the Baariks gallery to buy woven fabrics in an amount according to consumer needs

\section{Fixed Assets}

Fixed assets, in this case all the weaving tools and equipment as well as the place used to run the business, the informant emphasized that during the weaving business, all informants did it from their respective homes. This is because the woven fabric production process can be completed without having to have a business place that can be used by the craftsmen, enough from the craftsmen's house, they can produce woven fabrics and the place of business is sufficient to meet their production needs. Meanwhile, the tools and equipment used to do business are the tools and equipment that belong to the individual craftsmen. All the availability of tools and equipment up to the business premises used in running the handicraft weaving business have reached the craftsmen's satisfaction and comfort so that they can generate morale, and craftsmen's work can be completed quickly, precisely without experiencing significant obstacles. As for the satisfaction with the fixed assets owned by each craftsman, it is a success factor in running the weaving handicraft business, because all these fixed assets are completely in line with what the craftsmen need to support the weaving handicraft business that is already being carried out

\section{Turnover Business}

The circulation of money that occurs also follows the process of the business being carried out. It is also known that after the product has been woven and becomes ready-to-use goods, the craftsmen also have a relatively slow time selling their products. This applies to woven fabrics that are produced as inventory for later sale, if the woven fabric produced has entered the consumer's order list, the finished woven fabric does not take a long time to sell. Broadly speaking, this ikat craft business can be said to be a business that does require more time when compared to other businesses such as the food and beverage business. The process of producing woven fabrics itself also takes a considerable amount of time. Responding to this requires the knowledge, expertise and ability of a craftsman who acts as a business actor to use strategies and build efficient work mechanisms so that the craftsmen not experience obstacles in carrying out all processes in their business. Getting big results, craftsmen must try hard and hard to sell the woven fabrics they produce. And justifying that selling woven fabrics that have been produced is not as easy as selling food and beverage products, because consumer needs for woven fabrics also vary or change according to their respective needs. If there are no consumers who buy the woven fabrics they produce, the craftsmen automatically have to rack their brains hard so that the finished woven products can be sold so that the money can be returned by the craftsmen to run their business. The strategy and working mechanism that 
each craftsman strives for processing the finances obtained from the sale of woven fabrics is by having savings. This is done with the aim that the craftsmen can use their savings to make capital or turn the money back to run the weaving handicraft business.

\section{Cashflow}

Cash flow in the processing industry itself includes costs that come in and costs incurred both to buy business needs, production costs, marketing costs, the results obtained from the weaving handicraft business managed by craftsmen in what form, to the adequacy of the money earned is able to meet business needs are also the necessities of life of these craftsmen. The informant also explained that all the money obtained from the sale of tenun ikat had been arranged in such a way as for all cash posts required by the informant. business needs and household needs can be fulfilled from the cash management. The most important thing when the craftsman gets the proceeds from the sale of woven fabrics is to set aside for business needs such as buying threads, knick-knacks, processed woven fabrics. Then set aside for the needs of school children, household needs (eating and drinking), and finally set aside for savings. These Three Important Things are the main items of cash flow from the handicraft business that has been run by craftsmen. the money obtained is managed properly and appropriately so that the craftsmen almost never incur debt to continue the weaving handicraft business, let alone to meet the economic needs of each craftsman's household. All the results obtained can be managed properly so that all the items needed in the life of the craftsman can be fulfilled and the handicraft weaving business is also not neglected because of funds. This means that it can be concluded that proper cash flow management can be a success factor for the weaving handicraft business actors who are under the Bia Berek weaving group.

\section{Cost Structure}

This cost structure is explained again that in running the weaving handicraft business, the craftsmen who take shelter in the Bia Berek weaving group do not pay at all torrent weaving places, rent equipment and equipment for weaving. This is because since starting the weaving handicraft business, the place or location for weaving is in each house. So that there are no costs incurred to pay for the rent for a place or weaving location. Likewise with the tools and equipment for weaving, the craftsmen also do not incur similar costs because all the tools and equipment used for weaving are the craftsmen's personal property that can be designed by the craftsman themselves and according to the needs of the tools and equipment that have been used for years by the craftsmen. Running this woven handicraft business, the craftsmen already know and are familiar with all the costs that will be charged while running their business. And all costs incurred are smaller when compared to the results obtained from the sale of woven fabrics or the profits obtained. All costs incurred can be accounted for by the craftsmen with all forms of proper cost management mechanisms so that the craftsmen do not have to go into debt to continue business. The smaller the costs incurred and the more profits they get, the craftsmen can save and invest more for the continuity of their business and the continuity of their household economy. For this reason, the right cost structure factor is one of the success factors in the handicraft business of the weaving tie for the craftsmen who belong to the Bia Berek weaving group.

\section{Operating Revenues}

The processing industry does not go through a fast process in getting results from the business, craftsmen also try to stimulate consumers by 
making receivables. The mechanism is in accordance with that described by the craftsman that receivables given to customers are customers who can be trusted to pay all installments on time. This Is done to minimize losses due to defaults in payments. Both The customer and the craftsman will benefit not beat a disadvantage. The Fact That What Happens To the craftsmen who take shelter in the Bia Berek Weaving group is that while running the business of this ikat business, not all customers take the debt road to get woven fabrics, and not always the craftsmen provide receivables. From the customer cide, it is also seen by the craftsmen that the customer minimizes debts to the craftsmen in terms of purchasing woven fabrics. So that the handicraft weaving business does not experience obstacles from the mechanism to stimulate customers. Running a handicraft business in the processing industry takes time to get the results from the sale of its products. This can be completed in appropriate ways and according to the needs of the craftsman as well as the needs of the customer. Of course, not all businesses can apply this mechanism because every business has a different process of obtaining results. The business income factor experienced by the weaving craftsmen who are under the Bia Berek weaving group, actually makes business income a success factor experienced directly by the craftsmen in running a business because they don't experience obstacles that complicate their business. Business income in the handicraft of weaving, although it requires a process that is not fast, but the results of this business are always there and always sufficient for what is needed by the craftsmen. Craftsmen can feel satisfying results from what they get while running the weaving handicraft business as a measure to solve forest problems. Thus, it can be said that positive for by saving and having personal saving is also investing a certain amount of money in gold investment one of the success factors for craftsmen in terms of finance in order to minimize debt incurred, and using.

\section{Personal Savings and Investments}

Personal savings, both in savings and loans at banks or other financial service institutions, help the craftsmen to process all the money they get from the business to be used again if the craftsmen really need additional funds or additional money in carrying out the weaving craft. It is the same with investing in a form of investment such as gold that is purchased with the hope that it can be resold at a high price, given that the price of gold always increases every time. This makes craftsmen also willing to invest some of the profits they get for such things. In addition to being a reserve fund whenever needed, the money saved and invested is a way to minimize debt to craftsman if they are short funds. This craftsman belonging to the Bia Berek weaving group is more comfortable using his personal money to capitalize on his business, rather than using debt personal capital to run a business also has an emergency fund to continue the weaving business tie these.

\section{Non-Financial Factors \\ Marketing}

Efforts to introduce, promote and market woven fabric products that have been carried out and have had a positive impact are still being carried out. With the form of cooperation that is carried out between the related agencies and craftsmen, they both benefit for the development of both parties. The relevant agencies can realize the vision, mission and goals of their respective agencies for the success of their work programs. Likewise, craftsmen have benefited from the successful promotion and marketing of woven fabric products which are increasingly recognized by the wider community. This is proven by 
the participation of craftsmen in bringing their woven fabrics in various prestigious events held nationally and internationally. The efforts made by the relevant agencies by buying woven fabrics produced for the needs of the Atambua Weaving Gallery, make every month craftsmen's woven fabrics as well as processed products from woven fabrics that are produced can be sold continuously and automatically the craftsmen get additional customers. Of Course, with this cooperation in good marketing, it is hoped that the craftsmen will continue to run even more so that weaving from Belu Regency is better known, and the goal of preserving weaving is still carried out. Besides that, craftsmen who are SMEs can develop by increasing the sales of the handicrafts produced because each month the woven fabrics from the craftsmen are always taken by these agencies. Finally, the economy in Belu Regency in the industry can continue to develop until it becomes a successful business form even though it runs a business that is classified classic, such as the weaving business.

\section{Technology}

The use of technology can make craftsmen better known by the community at large both in the people of Belu Regency, as well as with those who are outside Belu Regency. This is due to the use of technology that is reached by social media to promote woven fabrics and processed products from woven fabrics which are also marketed on social media. Besides the craftsmen rely on their own abilities in using technology, craftsmen are also often assisted by their children who are more familiar with the use of technology. Then, in the use of technology, there are some consumers who take advantage of this by making applications to market wove handicraft products from craftsmen. This is not an obstacle or a competition for the craftsmen, but a source of assistance so that the supplies of woven fabrics produced by the craftsmen can be sold faster. Thus it can be concluded that in running the woven handicraft business run by the informants, they are very aware of the importance of using technology as success factor in their business because with the use of technology, craftsmen can attract more consumers who are far away from the craftsmen, technology can facilitate the promotion process and buying and selling of woven fabric products, as well as innovation in the use of technology can increase the development and growth of the woven hand craft business.

\section{Woven Fabric Quality}

The craftsmen always strive for the quality of woven fabrics and processed products from standard woven fabrics that are in accordance with consumer needs and in accordance with consumer demands so that satisfaction from consumers to craftsmen is maintained. As for the good quality of the product, making craftsmen do not lose cooperation with related agencies that have trusted craftsmen to become agents to take woven fabric products. With the good quality of the woven fabric, the craftsmen under the Bia Berek Weaving group are no less competitive with other ikat groups in Belu Regency. What Has been entrusted to the craftsmen regarding the quality of woven fabrics is always well maintained by the craftsmen, even enhanced by new innovations as well as more creativity with game motifs, mixing colors, or adjusting consumer demand following the trends of their time. So it can be concluded that good quality woven fabrics, and in accordance with what consumers need, is also a factor in the success of the weaving handicraft business that has been run by the craftsmen who are under the Bia Berek weaving group. Maintaining the quality of woven fabrics, making craftsmen trusted by consumers so that consumer satisfaction makes the handicraft 
business of handicraft woven from craftsmen always sought after by consumers, both from among the community and among related agencies both within Belu Regency and outside Belu Regency who make cooperation with craftsmen.

\section{Culture and Tradition}

The culture and tradition of using this woven cloth is one of the great potentials for craftsmen to run a woven handicraft business that already has a market among the community. The culture and tradition of using woven fabrics is directly a factor in the success of the hand-woven handicraft business that has been run by craftsmen. This is because the craftsmen are able to meet the needs of woven fabrics that are the target of consumers and are able to move forward according to the development of the times without losing the cultural and traditional values that exist in each of the woven motifs. Then, craftsmen are also fortunate to take advantage of this opportunity and potential well because in Atambua City, the weaving group whose mini gallery for selling woven fabrics can be reached by the community sb Bia Bertie weaving group. In addition, consumers can also meet craftsmen who are members of the Bia Berek Weaving group, to order woven fabrics, or design the motifs and colors of the woven fabrics according to consumer needs. This is an added value for craftsmen because being able to market woven fabrics in a place with culture and traditions is a must to have woven fabrics and can also meet consumer needs for the fulfillment of these woven fabrics. This positive business opportunity in the end brought the craftsmen under the Bia Berek weaving group, to become one of the advanced weaving business groups Blu Regency, Atambua City.

\section{Role of Government}

In Belu Regency, the handicraft weaving business has received moto assistance and support from the local government. The assistance and support referred to, either in the form of non-machine weaving tools, sewing tools, or in the form of materials such as pure grants to create a mini gallery of the Bia Berek weaving group. It does not stop there, support from the government is still continuing by making cooperation with craftsme no promote woven fabrics that have been produced. Support for this promotion by buying back woven fabrics that have been produced by craftsmen and then marketed back in the Atambua weaving gallery. This Is done to promote woven fabrics from craftsmen to tourists who come to tourists who come to tourists who come to visit Atambua, both national and international tourists. And this government effort has received a very good response and is developing from time to time as evidenced by the increasing number of national and international collaborations made by several parties with craftsmen through the local government of Belu Regency.

Another thing that has been shown to be a good impact of the government's role in the handicraft business of craftsmen is involving craftsmen in various forms of training and seminars related to the handicraft of weaving to develop the weaving business into a more advanced business and also teaching craftsmen as business actors engaged in processing industry in managing their business properly, both financially and non-financially. Of course, all the support from this government's role is with the aim of maintaining and preserving the weaving culture in Belu Regency, and advancing the weaving handicraft business which is also a promising addition a livelihood for business actors engaged in this field. Directly, the cooperation that has been going well, between the craftsmen and the government is a success factor for the craftsmen who run the weaving handicraft business. 


\section{The Design Model of the Construction of Success Factors for Ikat Weaving Craftsmen}

In accordance with the explanation above, it is revealed that the success factors in the weaving business include proper management of current assets (supplies of woven fabrics) and fixed assets (equipment and equipment for weaving and business premises), the ability to manage business turnover properly, cash flow management, capability processing all business costs in the cost structure, managing income for the weaving business, having personal savings and investing in non-bank financial services. Furthermore, other factors that are also a factor in the success of the woven handicraft business, namely increasing the marketing of woven fabrics, the use of technology for business innovation in the digital world, prioritizing the quality of woven fabrics produced, utilizing culture and tradition as business opportunities and potential, building profitable cooperation with local government Belu Regency. The twelve success factors are divided into two groups of success factors, name financial factors non-financial factors that have been previously described. This success factor has been directly expressed correctly, in accordance with what has been experienced, felt by the craftsmen who belong to the Bia Berek Weaving handicraft group. This success factor can change from time to time following the development and growth of the business because running business at any time requires innovation to move dynamically according to the times. As for explaining the success factors that have been divided into these two factors, it can be seen in Figure 1.

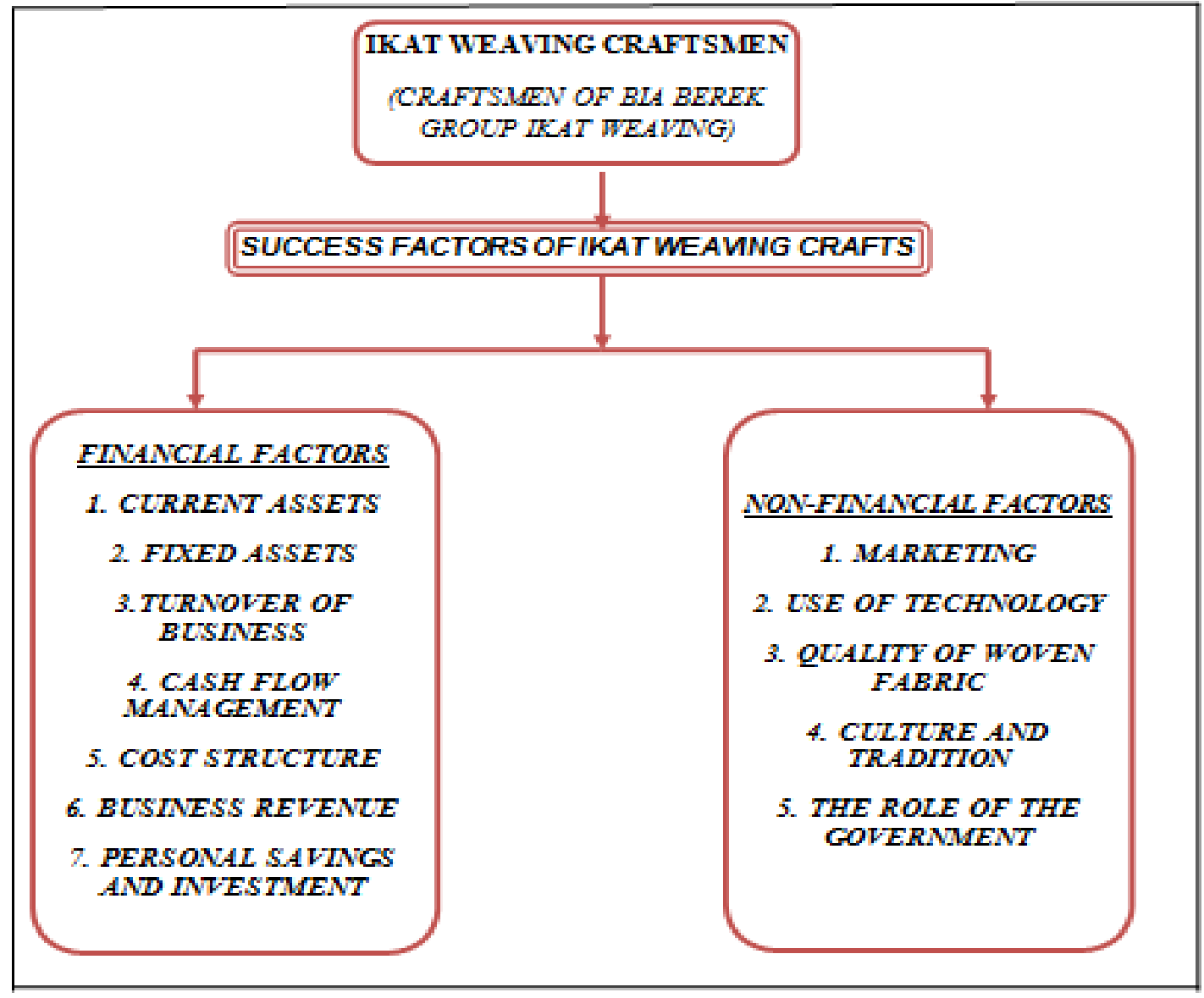

Source: Research Findings (2020)

Figure 1. Construction Model Design 
Current assets in the financial dimension refer to the inventory of processed woven fabrics, both in the form of manufactured woven fabrics and processed products from woven fabrics such as bags, accessories and others. The supply of woven fabrics is a smooth asset because in running a woven handicraft business, the main thing that must be fulfilled and provided regularly is woven fabric and processed products from woven fabrics. Fixed Assets refer to weaving equipment, weaving equipment and business premises for running a woven handicraft business. These three components are included in the financial dimension because in running a business, adequate tools and equipment and a place of business are needed to generate maximum profit for the weaving business actor. Weaving Tools and Equipment are also a major requirement in running a business so that the weaving business can run smoothly without certain obstacles. Business turnover refers to all the mechanisms, strategies and efforts made by craftsmen to process the finances generated from the sale of woven fabrics.

Mechanisms, strategies and efforts to rotate the results of the weaving business are needed by craftsmen to avoid delays in the entry of money that will be used again to run the business. Cash flow management refers to the ongoing process of incoming and outgoing cash including processing all costs incurred for business needs, so that what is generated and charged to run the business can be accounted for and meet all the needs of the craftsmen in running the business. The cost structure refers to all costs paid or incurred in running a woven handicraft business and sufficient money to pay for all these cost items, so as not to cause debt or difficulty for the craftsmen to account for these costs. Operating income refers to the income generated or obtained after the woven fabric is sold, to meet the business needs and economic needs of the craftsmen's household. And the process of accounts receivable carried out by craftsmen to stimulate the number of consumers in running a business. Personal savings and investment refer to saving and investment activities carried out by craftsmen to save a certain amount of funds in financial service institutions, either banks or others as well as investigating old purchases, which will be use dash emergency funds whenever the craftsmen need additional funds to run the weaving business. tie up. Marketing refers to the non-financial dimension, which is in the form of promotional activities and efforts to introduce woven handicraft businesses to the wider community both conventional and through the digital world (social media). The Use of technology refers to the skills and abilities of craftsmen in using technology to make it easier for craftsmen to meet consumers digitally, and to reach consumers from other areas, who need woven fabric products from craftsmen.

The quality of woven fabrics refers to the quality of a woven fabric product and the quality of goods that are reprocessed from woven fabrics, both from the play of motifs, colors, neatness and conformity with what is needed by consumers, which have become the hallmarks of craftsmen in producing quality woven fabric products. Culture and tradition refer to the opportunities and potentials developed by the craftsman considering that in Belu Regency, it has a culture and tradition of always using woven fabrics so that it is used as a positive advantage to continue to develop the handicraft business of weaving, which in fact already has enthusiasts. The role of the government refers to all the collaborations carried out by the government in Belu Regency for craftsmen, both involving craftsmen in various seminars, training weaving handicrafts, providing opportunities for craftsman to participate in various weaving handicraft events nationally and internationally and material assistance from government support.to preserve the weaving Belu Regency.

\section{CONCLUSIONS RECOMMENDATION}

Running a woven handicraft 
business, craftsmen experience firsthand the success of several financial and nonfinancial factors. The financial factors in question are the proper management of current assets (suppliers of woven fabrics) and fixed assets (weaving equipment and equipment and business premises), the ability to manage business turnover properly, manage cash flow, the ability to process all business costs in the cost structure, and management. income from a weaving business, have personal savings and investments in financial services other than banks. Meanwhile, non-financial factors include increasing the marketing of woven fabrics, using technology for business innovation in the digital world, prioritizing the quality of woven fabrics produced, utilizing culture and tradition as business opportunities and potential, building profitable cooperation with local governments in Belu Regency. The Success factor in terms of human resources, in this case the existence of employees to help all business processes in general, has always been a success factor for other business actors.

Infact, for the weaving craftsman who remembers of the weaving handicraft group, the existence of human resources (employees) to assist the craftsmen in running their business is not a factor in the success of their business. This is because the weaving handicraft business run by craftsmen is more dominant in relying on one's own strength without any help from other parties (employees) to assist the craftsmen in running the business. The use of technology to advance the business that craftsmen are trying to do is also not yet said to be sophisticated because while running the weaving handicraft business, craftsman still use simple methods such as delivery or other forms word of mouth promotion, and assistance from the promotion of other parties who prioritize the power of technology. This Is because the crafts do not have sufficient skills to use this technology, and there is no desire to try to develop business promotions on other media platforms. All the craftsmen who take shelter in the Bia Berek weaving group can survive continue their business even though they are faced with the conditions of the Covid-19 pandemic. The craftsmen experienced a decline in sales; however, they did not experience bankruptcy or business closure because they still had their own capital to continue their business and there were still customers who bought the woven fabrics. For craftsmen who run the weaving handicraft business, both in the Bia Berek weaving group, the Ikat weaving group outside Bia Berek and the craftsmen who run the ikat business individually, the results of the research can be used as a benchmark for developing the weaving handicraft business that is currently being run. by paying attention to the success factors of the business, so that these success factors can be increased for the sake of business sustainability and success of the weaving business.

For practitioners, researchers provide advice to the wider community, micro, small, and medium business actors who are running their business to pay attention, to know the importance of the success factors of the business, both from a financial and non-financial perspective, to be used as strengths, opportunities and potentials in achieving the target of successful business. desired. For the next research, researchers can carry out research to construct success factors for ikat craftsmen in other areas, so that comparisons can be found, differentiating factors for the success of ikat craftsmen who run the weaving handicraft business in various regions. Then the researcher can also conduct research to construct business success factors for business actors engaged in business industries tertial processing industries such as woven handicrafts.

\section{REFERENCES}

Chowdhury, M. S., Alam, Z., \& Arif, M. I. (2013). Success factors of entrepreneurs of small and medium sized enterprises: Evidence from Bangladesh. Business and Economic Research, 3(2), 38.

Gagnon, B., \& Hadaya, P. (2018). The four dimensions of Business Agility.

Hardjono, T., \& van Kemenade, E. (2021). The Empirical Paradigm, the Reference Paradigm, and the 
Reflective Paradigm. In The Emergence Paradigm in Quality Management (pp. 67-89). Springer.

Harris, F., McCaffer, R., Baldwin, A., \& Edum-Fotwe, F. (2021). Modern construction management. John Wiley \& Sons.

Kasmir. (n.d.). Manajemen Perbankan (1st-7th ed.). Jakarta: PT Raja. 2007.

Lauersen, K. J., Brown, A., Middleton, A., Davies, P. L., \& Walker, V. K. (2011). Expression and characterization of an antifreeze protein from the perennial ryegrass, Lolium perenne. Cryobiology, 62(3), 194-201.

Lo, M. C., Wang, Y. C., Wah, C. R. J., \& Ramayah, T. (2016). The critical success factors for organizational performance of SMEs in Malaysia: a partial least squares approach. Revista Brasileira de Gestão de Negócios, 18, 370-391.

Maher AL-MAHROUQ. (10 C.E.). Success Factors of Small and Medium-Sized Enterprises (SMEs): The Case Of Jordan. Anadolu University Journal of Social Sciences. Cilt. 2015, 1, 1-16.

Maher, B. (2014). Macaronic satire: making sense of nonsense in the parodies of Dario Fo and Sora Cesira. Comedy Studies, 5(2), 113-122.

Radzi, K. M., Nor, M. \&. M., \& Ali, S. M. (2017). The impact of internal factors on small business success: A case of small enterprises under the FELDA scheme. Asian Academy of Management Journal, 22(1), 27.

Rafiki, A., \& Nasution, F. N. (2019). Business success factors of Muslim women entrepreneurs in Indonesia. Journal of Enterprising Communities: People and Places in the Global Economy.

Sahu, O. (2018). Assessment of sugarcane industry: Suitability for production, consumption, and utilization. Annals of Agrarian Science, 16(4), 389-395.

Sale, J. E. M., \& Thielke, S. (2018). Qualitative research is a fundamental scientific process. Journal of Clinical Epidemiology, 102, 129-133.

Shan, M., Liu, W.-Q., Hwang, B.-G., \& Lye, J.-M. (2020). Critical success factors for small contractors to conduct green building construction projects in Singapore: identification and comparison with large contractors. Environmental Science and Pollution Research, 27(8), 8310-8322.

Wang, T., Zhai, Y., Zhu, Y., Gan, X., Zheng, L., Peng, C., Wang, B., Li, C., \& Zeng, G. (2018). Evaluation of the clean characteristics and combustion behavior of hydrochar derived from food waste towards solid biofuel production. Bioresource Technology, 266, 275-283. 